\title{
Metody wykrywania i pomiaru wielkości niezorganizowanej emisji metanu z elementów infrastruktury przesyłowej - wyniki projektu GERG Detection and Measurement of Fugitive Emissions of Natural Gas from the Transmission Systems
}

\section{Methods of detecting and measuring fugitive methane emissions from elements of the gas transmission infrastructure - the results of GERG project Detection and Measurement of Fugitive Emissions of Natural Gas from the Transmission Systems}

\author{
Eliza Dyakowska ${ }^{1}$, Adam Przybył ${ }^{2}$ \\ ${ }^{1}$ Izba Gospodarcza Gazownictwa \\ ${ }^{2}$ Operator Gazociągów Przesyłowych GAZ-SYSTEM S.A.
}

\begin{abstract}
STRESZCZENIE: W artykule przedstawiono wyniki projektu zrealizowanego przez GAZ-SYSTEM wspólnie z pięcioma innymi europejskimi operatorami systemów przesyłowych gazu - Enagás, Fluxys, Gasunie, Snam, GRTgaz. Celem projektu było zbadanie i wskazanie najbardziej przydatnych urządzeń do wykrywania i pomiaru wielkości emisji metanu z elementów infrastruktury typowych dla systemów przesyłowych. Analiza rynku pokazała, że dostępne są urządzenia do wykrywania emisji metanu wykorzystujące różne zasady działania, znacznie mniej jest natomiast urządzeń do pomiaru wielkości emisji. Do badań wybrano pięć urządzeń: trzy wyłącznie do detekcji, oparte na zasadzie działania D-1 (sensor półprzewodnikowy), D-2 (optyczny system na podczerwień), D-3 (technologia laserowa), oraz dwa urządzenia umożliwiające również pomiar emisji - P-1 (obrazowanie ultradźwiękowe) i P-2 (ilościowy system optycznego obrazowania gazu). Badania laboratoryjne przeprowadzono w marcu 2020 r. na stanowisku Enagás’ Metrological \& Innovation Center (M\&I) w Saragossie; zgodnie z przyjętym programem generowane były uchodzenia metanu z rozszczelnionych celowo zaworów, połączeń kołnierzowych, skręcanych oraz z przewodu otwartego do atmosfery. Badania polowe urządzeń w przypadku nieznanych nieszczelności wykonano na stacji pomiarowej przy M\&I. Celem badań była weryfikacja dokładności wytypowanych przyrządów pomiarowych; została ona przeprowadzona przy różnych strumieniach objętości i różnych stężeniach metanu w gazie uchodzącym z nieszczelności. Podczas badań oceniana była także m.in. łatwość stosowania urządzeń, szybkość wykrywania metanu i odległość urządzenia od miejsca uchodzenia gazu. Wyniki badań pokazały zarówno zalety, jak i ograniczenia poszczególnych urządzeń, wskazały ponadto jednoznacznie, że do oceny wielkości emisji metanu z elementów infrastruktury przesyłowej konieczne jest zastosowanie co najmniej dwóch różnych urządzeń. Uzyskane wyniki wskazują, że urządzenia typu sniffer, charakteryzujące się tym, że sonda musi się znaleźć w pobliżu miejsca uchodzenia, dają wyniki podobne do detektora FID, najczęściej stosowanego w programach LDAR (ang. leak detection and repair), ale mogą być stosowane w szerszym zakresie stężeń metanu. Urządzenie D-3 ma szybki czas odpowiedzi oraz szeroki zakres pomiarowy, jednak ze względu na jednostkę odczytu, tj. ppm-m, nie można przeliczyć wyników na stężenie metanu bez dodatkowego pomiaru odległości. P-1 oraz P-2 pozwalają na ocenę wielkości emisji metanu w czasie rzeczywistym - błędy pomiaru wielkości emisji dla obu urządzeń są porównywalne i wynoszą około $70 \%$ do $100 \%$.
\end{abstract}

Słowa kluczowe: emisja metanu, urządzenia do wykrywania metanu, urządzenia do pomiaru wielkości emisji metanu.

ABSTRACT: The article presents the results of the project carried out by GAZ-SYSTEM in cooperation with 5 other European gas Transmission System Operators (TSO) - ENAGAS, Fluxys, Gasunie, Snam and GRTgaz. The objective of the project was to investigate and identify the most useful devices for detecting and measuring methane emissions from infrastructure components typical for the TSO. The market analysis showed that methane detectors utilizing different principles of operation are available, but there are much fewer devices for measuring emission rates. 5 devices were selected for tests: 3 exclusively for detection based on the D- 1 (semiconductor sensor), D-2 (infrared optical gas detection system), D-3(laser technology) principle of operation, and 2 devices that also enable emissions measurement - P-1 (ultrasound imaging) and P-2 (quantitative optical gas imaging). Laboratory tests were carried out in

Autor do korespondencji: E. Dyakowska, e-mail: eliza.dyakowska@igg.pl

Artykuł nadesłano do Redakcji: 25.11.2020 r. Zatwierdzono do druku: 01.02.2021 r. 
March 2020 at the Enagás' Metrological \& Innovation Center (M\&I); according to the approved program, methane leaks were generated from deliberately unsealed valves, flanges, threaded and open-ended pipe connections. Field tests were carried out at the measuring gas station near the M\&I. The main purpose of the research was to verify the accuracy of the selected measuring instruments. It was carried out at different flowrate and various methane concentrations in the gas escaping from the components. Ease of use of the devices, their speed and range of operation were assessed. The results showed both the advantages and limitations of each device, and they clearly indicated that the assessment of methane emissions from gas transmission infrastructure components requires the use of at least two different devices. The results indicate that sniffer devices, characterized by the fact that the probe must be placed in the vicinity of the source of emission, give results similar to the FID Detector, most commonly used in Leak Detection and Repair (LDAR) programs, but can be used in a wider range of methane concentrations. D-3 has a fast response time and a wide measuring range, but their unit of measurement i.e. ppm-m prevents the conversion of the results into methane concentration without additional measurements of the distance between the leak and the device. The P-1 and P-2 allow to measure the emissions in real time, while the measurement errors for both devices are comparable, ranging from about $70 \%$ to $100 \%$.

Key words: methane emission, devices for methane detection, devices for methane emission quantification.

\section{Wprowadzenie}

Metan jest po $\mathrm{CO}_{2}$ drugim co do znaczenia gazem cieplarnianym pochodzenia antropogenicznego. W skali globalnej za 95\% emisji metanu spowodowanej przez człowieka odpowiedzialne są produkcja i transport paliw kopalnych, rolnictwo (głównie hodowla zwierząt oraz uprawa ryżu), a także utylizacja odpadów oraz oczyszczanie ścieków, co składa się na około $300 \mathrm{mln}$ ton metanu rocznie. Dla porównania emisja metanu spowodowana zjawiskami naturalnymi to około $260 \mathrm{mln}$ ton rocznie. Gleba oraz reakcje chemiczne w atmosferze powodują pochłanianie około 550 ton metanu, co sprawia, że co roku w atmosferze gromadzona jest nadwyżka wynosząca ok. $10 \mathrm{mln}$ ton (Global Carbon Atlas, 2019).

Siła oraz czas oddziaływania metanu na efekt cieplarniany mają charakter nieliniowy. $\mathrm{O}$ ile $\mathrm{CO}_{2}$ utrzymuje się w atmosferze przez stulecia, metan pozostaje w niej przez około dekadę, po czym ulega konwersji do $\mathrm{CO}_{2}$. Zwykle pomija się cieplarniany potencjał metanu w okresie 20 lat (GWP20), zamiast tego rozciąga się go na 100 lat, co powoduje, że gaz wydaje się mniej szkodliwy dla klimatu. GWP (ang. global warming potential) metanu dla 100 lat (GWP100) wynosi 34, według IPCC (Intergovernmental Panel on Climate Change) (Myhre et al., 2013), natomiast GWP20 wynosi około 84.

Przez tysiące lat stężenie metanu w atmosferze pozostawało na stałym poziomie, jednak w XIX wieku działalność człowieka doprowadziła do drastycznego wzrostu tej wartości (Yusuf et al., 2012). Utrzymujący się trend wzrostowy sprawił, że zmniejszenie emisji metanu stało się ważnym zagadnieniem oraz wyzwaniem także dla sektora nafty i gazu.

Szacuje się, że na poziomie globalnym przynajmniej połowa związanej z sektorem energetycznym emisji metanu może być zmniejszona bez poniesienia kosztów netto oraz że 5\% źródeł przyczynia się do $50 \%$ emisji (IEA, 2020). Emisja $\mathrm{CH}_{4}$ z obiektów systemu gazowego to tylko $0,6 \%$ całkowitej emisji $\mathrm{CH}_{4}$ w Europie (Gas Infrastructure Europe, Marcogaz, 2019). Na wykresie 1 przedstawiono udział poszczególnych części europejskiego łańcucha dostaw gazu ziemnego w całkowitej emisji metanu.

Pomimo wzrostu konsumpcji gazu oraz zwiększenia długości sieci przesyłowej w latach 1990-2016 emisja $\mathrm{CH}_{4}$ w UE zmniejszyła się o $51 \%$, głównie dzięki:

- doskonaleniu technologii stosowanych podczas budowy sieci;

- zmniejszaniu strat w dystrybucji;

- ograniczeniu wydobycia.

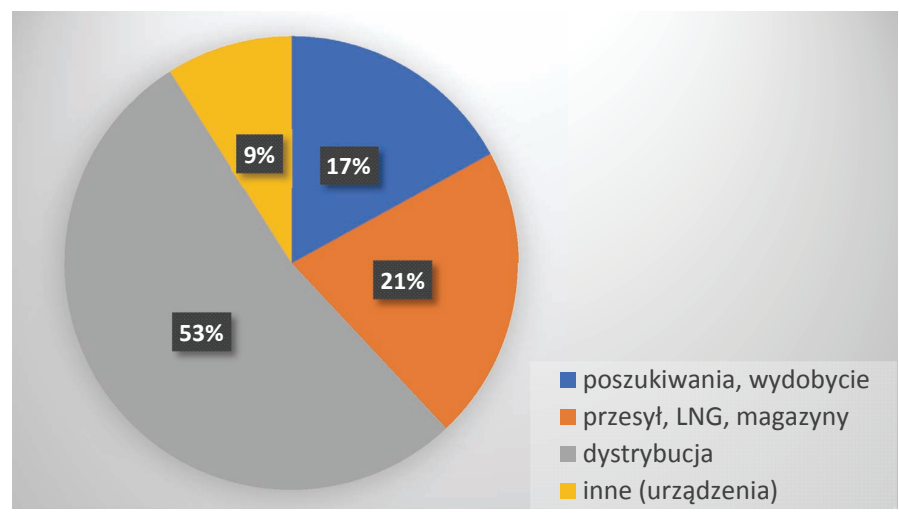

Rys. 1. Emisja $\mathrm{CH}_{4} \mathrm{w}$ Europie $\mathrm{z}$ łańcucha dostaw gazu ziemnego 2016 (Dyakowska i Przybył, 2020)

Fig. 1. $\mathrm{CH}_{4}$ emissions in Europe from the natural gas supply chain 2016 (Dyakowska and Przybył, 2020)

Ograniczanie emisji metanu jest jednym z priorytetowych celów Europejskiego Zielonego Ładu. Będąca jego częścią opublikowana 14 października 2020 r. Strategia metanowa przedstawia rozwiązania mające doprowadzić do dokładniejszego pomiaru, raportowania emisji metanu oraz sposobów jej zmniejszenia (European Commission, 2020). Świadomość konieczności ograniczenia niekorzystnych zmian klimatu przekłada się na wiele inicjatyw mających na celu zmniejszenie emisji metanu z całego łańcucha dostaw gazu ziemnego, do których należą:

- opracowanie przez Gas Infrastructure Europe (GIE) przy współpracy Marcogazu oraz wielu organizacji stowarzyszonych dla Forum Madryckiego, które odbyło się w czerwcu 
2019 r., raportu Potential way industry can contribute to the reduction of methane Emissions (Gas Infrastructure Europe, Marcogaz, 2019);

- opracowanie przez Marcogaz dokumentów: a) Prestandardization. Assessment of methane emissions for gas transmission and distribution system operators, który został następnie przekazany do CEN, oraz b) Recommendation for Leak Detection and Repair (LDAR) Programmes in the European Gas Sector (Transmission, UGS, LNG terminals and distribution), który będzie przedstawiony KE (Marcogaz, 2019);

- $\quad$ powstanie w CEN TC 234 grupy roboczej (WG 14), która ma opracować normę Assessment of methane emissions for gas transmission and distribution system operators. Do przedmiotowych prac PKN zgłosił przedstawiciela Polski;

- opracowanie w 2020 r. przez GERG (European Gas Research Group) mapy drogowej dotyczącej niezbędnych badań w zakresie zmniejszenia emisji metanu. Mapa drogowa zostanie przygotowana we współpracy z europejskimi operatorami sieci przesyłowych, którzy są członkami GERG, z uwzględnieniem ich potrzeb, i będzie stanowić punkt wyjścia do dalszych prac badawczych i nowych projektów realizowanych wspólnie;

- rozszerzenie inicjatywy OGMP (Oil \& Gas Methane Partnership 2.0), zrzeszającej firmy wydobywcze raportujące emisje metanu, o firmy zajmujące się przesyłem i dystrybucją gazu ziemnego, co zostało zasygnalizowane w komunikacie Komisji Europejskiej (European Commission, 2020); - opracowanie i opublikowanie w sierpniu 2020 r. przez Methane Guiding Principles (koalicja przemysłu, instytucji międzynarodowych, organizacji pozarządowych i naukowych) kolejnych dwóch Reducing Methane Emissions - Best Practice Guide (Methane Guiding Principles, 2020). Zmniejszanie emisji gazu ziemnego, składającego się głównie z metanu, wymaga, po pierwsze, lokalizacji miejsc, w których występuje emisja, podjęcia działań naprawczych oraz określenia wielkości tej emisji. Mając świadomość znaczenia wszelkich działań na rzecz zmniejszania emisji metanu, w 2018 r. sześciu operatorów europejskich - Snam, GRTgaz, Enagás, Fluxys, Gasunie oraz GAZ-SYSTEM jako lider projektu podpisali porozumienie o wspólnej realizacji projektu Detection and measurement of the emission of natural gas from the gas transmission system.

Celem projektu było wskazanie najlepszych dostępnych na rynku urządzeń do wykrywania i pomiaru wielkości emisji metanu $z$ elementów infrastruktury typowych dla sieci przesyłowej - co oczywiście nie wyklucza stosowania takich urządzeń w pozostałych częściach łańcucha dostaw, jak dystrybucja, magazynowanie, wydobycie, terminale LNG i inne.

Projekt został zakończony w 2020 r.

\section{Przyjęte założenia}

Założono, że urządzenia do wykrywania i pomiaru wielkości emisji będą stosowane lokalnie do poszczególnych źródeł emisji i mogą być użyte w programach LDAR. Jest to podejście typu bottom-up w odróżnieniu od metod top-down, w których wykrywa i szacuje się wielkość emisji z całych obiektów lub obszarów. W podejściu top-down stosowane są m.in. pojazdy, drony i systemy satelitarne, ale nie było ono brane pod uwagę w projekcie. Obecnie trwają jednak przygotowania do realizacji kolejnego projektu GERG o roboczej nazwie TopDown methodologies: detection \& quantification of methane emissions for transmission systems, UGS and LNG Terminals.

Przystępując do realizacji projektu, założono, że urządzenia do detekcji niezorganizowanych emisji metanu (lotnych) z infrastruktury systemów przesyłowych powinny obejmować jeden lub więcej z czterech podzakresów stężeń metanu: 10 ppm lub mniej, między 10 ppm a 10000 ppm, między 10000 ppm a 100000 ppm oraz od 100000 ppm do 1000000 ppm, natomiast urządzenia do pomiaru wielkości emisji - jeden lub więcej z trzech podzakresów:

- poniżej 1,42 1/min (około $530 \mathrm{~kg} \mathrm{CH}_{4} /$ rok);

- $1,42 \mathrm{l} / \mathrm{min}$ do $226 \mathrm{l} / \mathrm{min}(530-85000 \mathrm{~kg} / \mathrm{rok}) ;$

- $\quad$ ponad $226 \mathrm{l} / \mathrm{min}$ (około $85000 \mathrm{~kg} / \mathrm{rok}$ ).

Wskazane zakresy pomiarowe dla urządzeń do pomiaru wielkości emisji wynikały z zakresu pomiarowego urządzenia Hi Flow Sampler (Dyakowska i Pęgielska, 2016), stosowanego zarówno przez GAZ-SYSTEM, jak i innych operatorów europejskich w pracach badawczych, których celem był pomiar wielkości emisji lotnych ze zidentyfikowanych źródeł.

Analiza dostępnych na rynku urządzeń, które mogą zostać wykorzystane przez służby eksploatacyjne do pomiaru okresowego, pokazała jednak, że przyjęte założenia były zbyt optymistyczne, a wybór dostępnych urządzeń jest znacznie bardziej ograniczony, niż zakładano. W szczególności dotyczy to urządzeń do pomiaru wielkości emisji metanu.

W tabeli 1 przedstawiono zarówno dostępne, jak i będące na etapie opracowywania metody pomiaru wielkości emisji metanu wymienione w dokumencie Methane Guiding Principles. Reducing Methane Emissions: Best Practice Guide Identification, Detection, Measurement and Quantification, opublikowanym we wrześniu 2020 r. Obrazowanie ultradźwiękowe zostało w nim uwzględnione dzięki realizacji w tym samym czasie, w którym powstawał ten dokument, omawianego projektu GERG. Przedstawiciele wszystkich operatorów uczestniczących w projekcie brali udział w opracowaniu ww. podręcznika dobrych praktyk (ang. best practice guide).

W projekcie GERG brano pod uwagę tylko urządzenia stosowane w podejściu bottom-up, natomiast w tabeli 1 uwzględniono także metody stosowane w podejściu top-down. 
Tabela 1. Metody pomiaru wielkości emisji metanu z systemu gazu ziemnego

Table 1. Methods of measurement of methane emissions from natural gas system

\begin{tabular}{|c|c|c|c|c|c|}
\hline Sposób pomiaru & Technologia & $\begin{array}{l}\text { Metoda pomiaru/ } \\
\text { ujęcia ilościowego }\end{array}$ & Dokładność & Zalety i wady & $\begin{array}{l}\text { Stosowanie w sekto- } \\
\text { rach gazu ziemnego }\end{array}$ \\
\hline \multirow{7}{*}{$\begin{array}{l}\text { Obchód pieszy, } \\
\text { do poszczegól- } \\
\text { nych źródeł }\end{array}$} & $\begin{array}{l}\text { urządzenie próbkujące } \\
\text { typu sniffer, takie jak de- } \\
\text { tektor FID lub półprze- } \\
\text { wodniki o wysokiej czu- } \\
\text { łości, które pobierają } \\
\text { próbki z powietrza }\end{array}$ & $\begin{array}{l}\text { pośrednia, stosowane } \\
\text { równania korelacyj- } \\
\text { ne (zależność stęże- } \\
\text { nia i przepływu) lub } \\
\text { współczynniki emisji }\end{array}$ & $\begin{array}{l}\text { średnia do } \\
\text { wysokiej }\end{array}$ & $\begin{array}{l}\text { zalety: istnieją dobrze udo- } \\
\text { kumentowane metody (patrz } \\
\text { PN-EN 15446) } \\
\text { wady: konieczność wykony- } \\
\text { wania obliczeń po przepro- } \\
\text { wadzeniu badań }\end{array}$ & $\begin{array}{c}\text { wszystkie, dla } \\
\text { instalacji naziemnych }\end{array}$ \\
\hline & $\begin{array}{l}\text { próbkowanie przepływu } \\
\text { (urządzenie zasysa wy- } \\
\text { starczającą ilość powie- } \\
\text { trza, aby zebrać całość } \\
\text { uchodzącego metanu) }\end{array}$ & bezpośrednia & wysoka & $\begin{array}{l}\text { zalety: wynik w czasie rze- } \\
\text { czywistym } \\
\text { wady: urządzenie HFS prze- } \\
\text { stało być produkowane*, po- } \\
\text { miary czasochłonne, dolny } \\
\text { zakres pomiarowy często za } \\
\text { duży w przypadkach ucho- } \\
\text { dzeń w dystrybucji }\end{array}$ & wszystkie \\
\hline & $\begin{array}{l}\text { optyczne obrazowanie } \\
\text { uchodzenia gazu plus } \\
\text { odpowiednie oprogra- } \\
\text { mowanie (technologia } \\
\text { wchodząca) }\end{array}$ & pośrednia & $\begin{array}{l}\text { niska do } \\
\text { średniej }\end{array}$ & $\begin{array}{l}\text { zalety: pomiar w czasie rze- } \\
\text { czywistym } \\
\text { wady: zależność od warun- } \\
\text { ków otoczenia, słabo spraw- } \\
\text { dza się przy bardzo dużych } \\
\text { emisjach oraz małych wystę- } \\
\text { pujących w dystrybucji, wy- } \\
\text { maga szkolenia }\end{array}$ & wszystkie \\
\hline & $\begin{array}{l}\text { rurka Pitota, przepływo- } \\
\text { mierz masowy lub inny } \\
\text { wstawiony w miejsce } \\
\text { uchodzenia gazu, takie } \\
\text { jak np. kolumna wydmu- } \\
\text { chowa }\end{array}$ & bezpośrednia & wysoka & $\begin{array}{l}\text { zalety: pomiar bezpośredni } \\
\text { wady: problemem jest często } \\
\text { bezpośredni dostęp do źró- } \\
\text { dła emisji }\end{array}$ & $\begin{array}{l}\text { wszystkie, w których } \\
\text { są kolumny } \\
\text { wydmuchowe }\end{array}$ \\
\hline & worki kalibrowane & bezpośrednia & wysoka & $\begin{array}{l}\text { zalety: niedrogie, dokładne } \\
\text { wady: czasochłonne i praco- } \\
\text { chłonne }\end{array}$ & $\begin{array}{c}\text { wszystkie, w których } \\
\text { występują uchodzenia } \\
\text { o odpowiedniej } \\
\text { wielkości }\end{array}$ \\
\hline & $\begin{array}{l}\text { komora, do której wpły- } \\
\text { wa uchodzący gaz (obu- } \\
\text { dowa wokół miejsca } \\
\text { uchodzenia, mierzone } \\
\text { jest stężenie zasysane- } \\
\text { go gazu) }\end{array}$ & bezpośrednia & średnia & $\begin{array}{l}\text { zalety: nie zależy od mo- } \\
\text { delowania warunków oto- } \\
\text { czenia } \\
\text { wady: emisja tylko z obszaru } \\
\text { obudowanego, metoda pra- } \\
\text { cochłonna }\end{array}$ & $\begin{array}{l}\text { przesył i dystrybucja, } \\
\text { dla uchodzeń z gazo- } \\
\text { ciągów podziemnych }\end{array}$ \\
\hline & $\begin{array}{l}\text { obrazowanie ultradź- } \\
\text { więkowe (technologia } \\
\text { wchodząca) }\end{array}$ & pośrednia & $\begin{array}{l}\text { prawdopo- } \\
\text { dobnie } \\
\text { średnia }\end{array}$ & $\begin{array}{l}\text { zalety: w czasie rzeczywi- } \\
\text { stym, szybka } \\
\text { wady: wymaga spadku ci- } \\
\text { śnienia, oprogramowanie dla } \\
\text { metanu dopiero powstaje }\end{array}$ & wszystkie \\
\hline \multirow{3}{*}{$\begin{array}{l}\text { Czujniki w jed- } \\
\text { nym miejscu } \\
\text { (np. w linii ogro- } \\
\text { dzenia) }\end{array}$} & $\begin{array}{l}\text { absorpcja światła na } \\
\text { otwartej ścieżce }\end{array}$ & \multirow{3}{*}{$\begin{array}{l}\text { tylko pośrednia, moż- } \\
\text { liwa przy dodatko- } \\
\text { wym modelowaniu } \\
\text { i informacjach mete- } \\
\text { orologicznych }\end{array}$} & średnia & $\begin{array}{l}\text { zalety: technologia dostępna } \\
\text { wady: koszty }\end{array}$ & \multirow{3}{*}{$\begin{array}{c}\text { produkcja, przesył } \\
\text { i dystrybucja z dużą } \\
\text { populacją urządzeń } \\
\text { naziemnych }\end{array}$} \\
\hline & $\begin{array}{l}\text { czujniki punktowe na } \\
\text { obiekcie }\end{array}$ & & średnia & w opracowaniu & \\
\hline & $\begin{array}{l}\text { czujniki punktowe } \\
\text { w sieci }\end{array}$ & & $\begin{array}{l}\text { średnia do } \\
\text { małej }\end{array}$ & w opracowaniu & \\
\hline
\end{tabular}


cd. Tabela $1 /$ cont. Table 1

\begin{tabular}{|c|c|c|c|c|c|}
\hline Sposób pomiaru & Technologia & $\begin{array}{l}\text { Metoda pomiaru/ } \\
\text { ujęcia ilościowego }\end{array}$ & Dokładność & Zalety i wady & $\begin{array}{l}\text { Stosowanie w sekto- } \\
\text { rach gazu ziemnego }\end{array}$ \\
\hline \multirow{2}{*}{$\begin{array}{l}\text { Badanie za po- } \\
\text { mocą pojazdów } \\
\text { kołowych }\end{array}$} & $\begin{array}{l}\text { pojazd z czujnikiem } \\
\text { metanu oraz analiza } \\
\text { wykorzystująca informa- } \\
\text { cje meteorologiczne } \\
\text { i modelowanie odwrot- } \\
\text { nej dyspersji }\end{array}$ & pośrednia & $\begin{array}{l}\text { średnia do } \\
\text { małej }\end{array}$ & $\begin{array}{l}\text { zalety: do wielu zastosowań, } \\
\text { wady: obliczenia wielkości } \\
\text { emisji po badaniu }\end{array}$ & $\begin{array}{c}\text { wszystkie dla nad- } \\
\text { ziemnych instalacji } \\
\text { z możliwością dojaz- } \\
\text { du w pobliże lub pod- } \\
\text { ziemnych gazociągów } \\
\text { z dostępem dla po- } \\
\text { jazdów }\end{array}$ \\
\hline & $\begin{array}{l}\text { pojazd z czujnikiem me- } \\
\text { tanu i uwalnianie znacz- } \\
\text { nika }\end{array}$ & $\begin{array}{l}\text { bezpośrednia, tylko } \\
\text { współczynniki są po- } \\
\text { trzebne do określenia } \\
\text { wielkości emisji }\end{array}$ & $\begin{array}{l}\text { średnia do } \\
\text { małej }\end{array}$ & $\begin{array}{l}\text { zalety: dobrze znana } \\
\text { i sprawdzona } \\
\text { wady: pracochłonna, do- } \\
\text { kładność zależy od położe- } \\
\text { nia emisji znacznika i źródła } \\
\text { uchodzenia }\end{array}$ & $\begin{array}{l}\text { wszystkie, ale głów- } \\
\text { nie produkcja i mid- } \\
\text { stream }\end{array}$ \\
\hline $\begin{array}{l}\text { Badania za po- } \\
\text { mocą dronów lub } \\
\text { UAV }\end{array}$ & $\begin{array}{l}\text { model bilansu masy } \\
\text { (pomiary z wiatrem } \\
\text { i pod wiatr, ścieżka } \\
\text { przelotu obejmuje źródło } \\
\text { uchodzenia }\end{array}$ & bezpośrednia & niska & $\begin{array}{l}\text { zalety: stosunkowa tania } \\
\text { w stosunku do innych metod } \\
\text { top-down } \\
\text { wady: niewielu dostawców, } \\
\text { wymaga korzystnych warun- } \\
\text { ków atmosferycznych }\end{array}$ & upstream i midstream \\
\hline \multirow{3}{*}{$\begin{array}{l}\text { Badanie za po- } \\
\text { mocą samolotów }\end{array}$} & $\begin{array}{l}\text { bilans masy, przelot z } \\
\text { wiatrem i pod wiatr }\end{array}$ & bezpośrednia & $\begin{array}{l}\text { średnia (wy- } \\
\text { soka, jeśli na } \\
\text { drodze prze- } \\
\text { lotu pojedyn- } \\
\text { czy obiekt) }\end{array}$ & $\begin{array}{l}\text { zalety: rozwiązanie recen- } \\
\text { zowane } \\
\text { wady: kosztowna, niewie- } \\
\text { lu dostawców, wymaga ko- } \\
\text { rzystnych warunków atmos- } \\
\text { ferycznych }\end{array}$ & $\begin{array}{l}\text { wszystkie, jednak } \\
\text { mniej w dystrybucji }\end{array}$ \\
\hline & $\begin{array}{l}\text { pasywna absorpcja } \\
\text { światła }\end{array}$ & $\begin{array}{l}\text { pośrednia, stosowa- } \\
\text { ne jest modelowanie } \\
\text { pikseli chmury }\end{array}$ & niska & $\begin{array}{l}\text { zalety: wielu dostawców } \\
\text { wady: niska dolna grani- } \\
\text { ca wykrywania, duża nie- } \\
\text { pewność }\end{array}$ & wszystkie \\
\hline & $\begin{array}{l}\text { aktywna absorpcja } \\
\text { światła }\end{array}$ & $\begin{array}{l}\text { pośrednia, stosowa- } \\
\text { ne jest modelowanie } \\
\text { pikseli chmury }\end{array}$ & średnia & $\begin{array}{l}\text { zalety: technologia spraw- } \\
\text { dzona } \\
\text { wady: tylko kilku dostaw- } \\
\text { ców }\end{array}$ & wszystkie \\
\hline \multirow{3}{*}{$\begin{array}{l}\text { Badanie za po- } \\
\text { mocą satelitów } \\
\text { (planowane są sa- } \\
\text { telity wykrywają- } \\
\text { ce metan) }\end{array}$} & $\begin{array}{l}\text { spektrometria TROPO- } \\
\text { MI (The TROPOspheric } \\
\text { Monitoring Instrument) }\end{array}$ & $\begin{array}{l}\text { pośrednia. Stosowa- } \\
\text { ne jest modelowanie } \\
\text { pikseli chmury }\end{array}$ & średnia & $\begin{array}{l}\text { wady: wymaga znacznego } \\
\text { przetwarzania informacji sa- } \\
\text { telitarnych w celu oszacowa- } \\
\text { nia emisji }\end{array}$ & wszystkie \\
\hline & $\begin{array}{l}\text { spektrometria } \\
\text { (satelita wykrywający } \\
\text { metan ma być wysłany } \\
\text { w } 2022 \text { r.) }\end{array}$ & $\begin{array}{l}\text { pośrednia. Wymaga } \\
\text { intensywnego prze- } \\
\text { twarzania danych }\end{array}$ & nieznana & $\begin{array}{l}\text { zalety: bezpłatna, częsta } \\
\text { i publicznie dostępna } \\
\text { wady: jeszcze nie urucho- } \\
\text { miona }\end{array}$ & wszystkie \\
\hline & $\begin{array}{l}\text { spektrometria, Wide- } \\
\text { Angle Fabry-Perot GHG } \\
\text { Sat }\end{array}$ & pośrednia & nieznana & $\begin{array}{l}\text { zalety: dostępna } \\
\text { wady: usługa płatna niewie- } \\
\text { le mikrosatelitów obecnie na } \\
\text { orbicie }\end{array}$ & wszystkie \\
\hline
\end{tabular}

* Instytut Nafty i Gazy - Państwowy Instytut Badawczy w latach 2010-2014 wykonywał na zlecenie GAZ-SYSTEM pomiary wielkości emisji metanu z obiektów systemu przesyłowego z użyciem HFS. Według informacji udostępnionych na spotkaniu GERG w maju 2020 r. przez przedstawiciela PG\&E, na Colorado State University trwają prace nad nową wersją HFS o tej samej zasadzie działania, ale o lepszej dokładności.

Początkowo jako urządzenie do pomiaru wielkości emisji wytypowano jedynie P-2 i w ostatniej chwili nawiązano kontakt z producentem urządzenia akustycznego P-1.

Do badań wybrano ostatecznie trzy urządzenia do detekcji metanu oraz dwa do pomiaru wielkości emisji, wymienione w tabeli 2 .
D-1 oraz D-2 służą do detekcji metanu i pomiaru jego stężenia, są to urządzenia typu sniffer, których zakres pomiarowy obejmuje stężenia od zera do $100 \%$ zawartości metanu.

D-3 służy do detekcji metanu i określa gęstość kolumny metanu. Pomiar dokonywany jest w pewnej odległości od miejsca uchodzenia. 
Tabela 2. Urządzenia wytypowane do badań

Table 2. Devices selected for tests

\begin{tabular}{|c|c|c|c|c|c|}
\hline Urządzenie & D-1 & D-2 & D-3 & P-1 & P-2 \\
\hline Typ czujnika & bardzo czuły półprzewodnik & ICIPS & TDLAS & ultradźwiękowy & na podczerwień \\
\hline $\begin{array}{l}\text { Detekcja: (ppm lub ppm-m) } \\
\text { Pomiar: (1/min) }\end{array}$ & $\begin{array}{c}\text { ppm całkowitej zawartości } \\
\text { węgla }\end{array}$ & ppm metanu & ppm-m metanu & $1 /$ min dowolnego gazu $^{*}$ & $\begin{array}{l}\text { 1/min różne } \mathrm{VOC}^{* *} \\
\text { łącznie } \mathrm{z} \text { metanem }\end{array}$ \\
\hline
\end{tabular}

${ }^{*}$ Urządzenie z czujnikiem ultradźwiękowym nie rozróżnia rodzaju emitowanego gazu.

${ }^{* *}$ ang. volatile organic compounds

P-1 służy do detekcji oraz pomiaru wielkości emisji gazu. Zawiera kamerę do zobrazowania uchodzenia w czasie rzeczywistym oraz 149 bardzo czułych mikrofonów do zdalnego wykrywania fal ultradźwiękowych wytwarzanych przez uchodzący gaz. Zakres pomiarowy urządzenia wynosi od $0,03 \mathrm{l} / \mathrm{min}$ do 167 1/min, a teoretyczna dokładność deklarowana przez producenta to $\pm 50 \%$ (do $167 \mathrm{l} / \mathrm{min}$ ). Opracowanie odpowiedniego oprogramowania umożliwiło także oszacowanie wielkości emisji; oprogramowanie jest nadal rozwijane. Ograniczeniem jest również konieczność wystąpienia odpowiednio dużej różnicy ciśnień (50 mbar) między ciśnieniem w gazociągu lub instalacji a otoczeniem i zależność dokładności od występowania innych źródeł ultradźwięków.

System P-2 łączy obrazowanie uchodzenia za pomocą kamery z możliwościami oszacowania wielkości emisji za pomocą dedykowanego oprogramowania. Dolna granica zakresu pomiarowego urządzenia to około $0,4 \mathrm{l} / \mathrm{min}$, a teoretyczna dokładność deklarowana przez producenta wynosi $\pm 40 \%$ do $300 \mathrm{l} / \mathrm{min}$. Ograniczeniem tej metody jest minimalna wielkość uchodzenia równa około 0,4 1/min i różnica temperatur między uchodzącym gazem i tłem, która nie może być mniejsza niż $2^{\circ} \mathrm{C}$.

\section{Metodyka badań}

Celem badań laboratoryjnych było zweryfikowanie właściwości użytkowych wytypowanych urządzeń oraz ich dokładności. Oceniano następujące parametry:

1. Szybkość działania: została ona scharakteryzowana przez:

a) start-up time - czas między włączeniem urządzenia i jego gotowością do użycia;

b) czas odpowiedzi - czas reakcji urządzenia na gaz uchodzący z rozszczelnionego elementu lub otwartego przewodu; c) czas potrzebny do uzyskania stabilnego wyniku.

2. Odległość od źródła nieszczelności: w przypadku urządzeń D-1 oraz D-2 czujnik musi być w kontakcie z powierzchnią, z której może następować uchodzenie. W przypadku pozostałych urządzeń generowano uchodzenie $100 \%$ metanu przy przepływie około $2 \mathrm{l} / \mathrm{min}$ i testowano odpowiedź urządzeń z odległości $0,5 \mathrm{~m}$ do $9 \mathrm{~m}$.

3. Zakres pomiarowy: D-1 oraz D-2 mają zakres pomiarowy od 0 ppm do $100 \% \mathrm{CH}_{4}$, obserwowano wskazania pozostałych urządzeń na generowaną wielkość uchodzeń.

4. Dokładność urządzenia: błąd wskazania określano jako różnicę między wielkością zmierzoną a wielkością poprawną strumienia objętości.

5. Powtarzalność wskazań: obliczano odchylenie standardowe po wykonaniu każdym urządzeniem 10 pomiarów uchodzenia metanu z połączenia gwintowanego przy kontrolowanym przepływie w zakresie 2,0 1/min ( $+3,0 \mathrm{l} / \mathrm{min})$.

6. Łatwość stosowania: jako kryterium przyjęto czas potrzebny do opanowania obsługi urządzenia przez operatora.

W badaniach zostały wykorzystane połączenia gwintowane oraz zawory i kołnierze specjalnie rozszczelnione podczas realizacji projektu GERG 2.73 Detection and measurement of the emission of natural gas from the transmission system, zakończonego w 2014 r. (Dyakowska et al., 2014), które zostały udostępnione przez GRTgaz.

Zakres strumieni objętości wynosił od 0,4 1/min do 20 1/min z następujących powodów:

- przepływ gazu przez rozszczelnienia zaworu, kołnierza, połączenia gwintowanego oraz przewód otwarty do atmosfery odpowiada temu zakresowi i nie mógł być zmieniany podczas badań;

- dokładność zastosowanego regulatora przepływu Bronkhorst In-Flow F-211AI jest gorsza przy większych przepływach;

- konieczność zapewnienia bezpieczeństwa.

Stężenia metanu w każdej butli zasilającej stanowisko laboratoryjne wynosiły odpowiednio: $0,5 \%, 2,5 \%, 50 \%$ i 99,5\%, zgodnie z certyfikatem dostawcy $\pm 2 \%$. Ciśnienie na wlocie do stanowiska było stałe (regulowane automatycznie) i wynosiło 30 bar.

W artykule przedstawiono szczegółowo wyniki badań parametrów metrologicznych dla dwóch urządzeń do pomiaru wielkości emisji.

\section{Badania laboratoryjne}

Badania laboratoryjne prowadzono na stanowisku wykonanym przez Enagás w Enagás' Metrological \& Innovation Center (M\&I) w Saragossie i udostępnionym partnerom projektu. Schemat stanowiska pokazano na rysunku 1. 


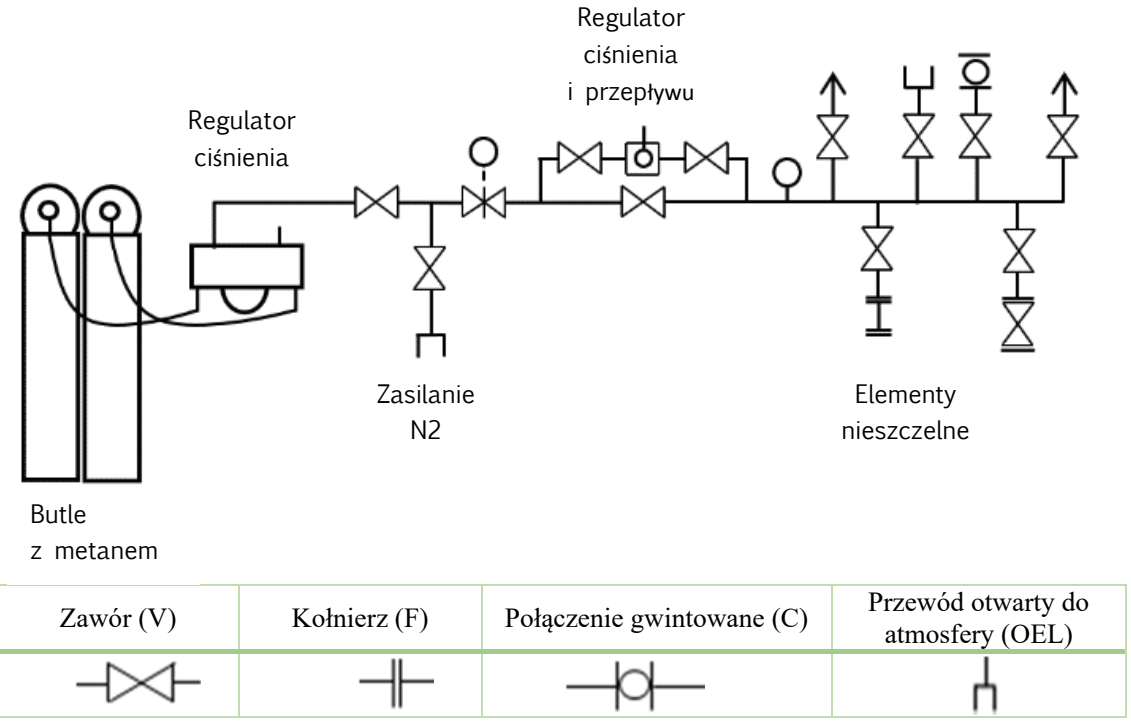

Rys. 2. Schemat stanowiska laboratoryjnego

Fig. 2. Scheme of the laboratory testing facility „min” (średnia - odchylenie standardowe) i ,max” (średnia + odchylenie standardowe).

Kamera P-2, aby uzyskane wyniki pomiaru były stabilne, musi być zamontowana na statywie. Wynik każdego pomiaru jest wartością średnią z odczytów chmury gazu wykonywanych w ciągu 10 sekund, a ponieważ w tym czasie chmura może zmieniać kształt, z uwagi m.in. na warunki atmosferyczne, powtarzalność (odchylenie standardowe dla pierwszych ośmiu pomiarów) jest gorsza niż w przypadku P-1.

Wyniki od 1 do 8 wskazują na bardzo dobrą powtarzalność, jednak wyniki pomiarów 9 i 10 wyraźnie się różnią, co świadczy o tym, że zmiana kąta widzenia oraz ustawień urządzenia zasadniczo zmienia wynik.

\section{Wyniki badań dokładności}

Poniżej podano przykładowe wyniki badań dwóch urządzeń służących do pomiaru wielkości emisji: w tabeli 3 dla P-1 oraz w tabeli 4 dla P-2. Podane wartości błędów zostały obliczone jako wartość średnia z dwóch pomiarów, które nie były wykonywane jeden po drugim.

Jedną z przyczyn występowania wyników odstających (ang. outliers) są trudności w ustawieniu statywu kamery tak, aby uzyskać najlepszy pomiar, znaczenie ma także różnica temperatur między chmurą gazu a tłem.

\section{Wyniki badań odtwarzalności}

Celem badań było wyznaczenie powtarzalności, co przedstawiono na rysunkach 3 i 4 . W obliczeniach uwzględniono jednak także wyniki dwóch wcześniej wykonanych pomiarów, uzyskano więc w praktyce odtwarzalność wyników uzyskiwanych przez poszczególne urządzenia. Wykonano osiem kolejnych pomiarów emisji metanu o stężeniu $100 \%$ z połączenia gwintowanego, ale przy obliczaniu odchylenia standardowego, które przyjęto za miarę powtarzalności, uwzględniono dwa wyniki wcześniej uzyskanych pomiarów przy tej samej wielkości strumienia objętości. Na podstawie wcześniej wykonanych dwóch pomiarów wyznaczono błędy poszczególnych urządzeń. Poniższe wykresy przedstawiają wyniki pomiarów, wartości średnie oraz odchylenia od średniej rozumiane jako
Tabela 3. Wyniki pomiarów wykonanych urządzeniem P-1

Table 3. Results of measurements made with the P-1 device

\begin{tabular}{|c|c|c|c|c|}
\hline \multirow{2}{*}{$\begin{array}{c}\text { Stężenie } \\
\text { metanu }^{* *} \\
{[\%]}\end{array}$} & \multirow{2}{*}{$\begin{array}{l}\text { Nieszczelny } \\
\text { element } \\
\text { (wg rys. 2) }\end{array}$} & \multicolumn{2}{|c|}{ Strumień objętości [l/min] } & \multirow{2}{*}{$\begin{array}{c}\text { Bląd } \\
{[\%]}\end{array}$} \\
\hline & & rzeczywisty & zmierzony & \\
\hline \multirow{12}{*}{100} & $\mathrm{~V}$ & 0,55 & 0,83 & 52 \\
\hline & V & 2,49 & 2,42 & -3 \\
\hline & $\mathrm{V}$ & 15,90 & 4,83 & -70 \\
\hline & $\mathrm{F}$ & 0,62 & 0,31 & -50 \\
\hline & $\mathrm{F}$ & 1,52 & 0,57 & -63 \\
\hline & $\mathrm{F}$ & 2,10 & 0,83 & -60 \\
\hline & $\mathrm{C}$ & 0,50 & 1,50 & 203 \\
\hline & $\mathrm{C}$ & 2,10 & 8,42 & 304 \\
\hline & OEL & 0,50 & brak odczytu* & brak odczytu* \\
\hline & OEL & 2,00 & brak odczytu* & brak odczytu $^{*}$ \\
\hline & OEL & 10,00 & 0,53 & -95 \\
\hline & OEL & 20,00 & 6,83 & -66 \\
\hline \multirow{5}{*}{50} & $\mathrm{~V}$ & 3,35 & 4,33 & 30 \\
\hline & $\mathrm{F}$ & 1,91 & 0,75 & -61 \\
\hline & $\mathrm{C}$ & 1,81 & 2,83 & 57 \\
\hline & OEL & 2,27 & brak odczytu* $^{*}$ & brak odczytu* $^{*}$ \\
\hline & OEL & 1,34 & 1,75 & -85 \\
\hline \multirow{6}{*}{2,5} & $\mathrm{~V}$ & 0,57 & 1,83 & 222 \\
\hline & $\mathrm{V}$ & 4,20 & 4,00 & -5 \\
\hline & $\mathrm{F}$ & 2,03 & 0,68 & -66 \\
\hline & $\mathrm{C}$ & 1,78 & 5,83 & 228 \\
\hline & OEL & 1,95 & brak odczytu* & brak odczytu* \\
\hline & OEL & 13,00 & 1,33 & -90 \\
\hline \multirow{5}{*}{0,5} & $\mathrm{~V}$ & 0,72 & 2,17 & 201 \\
\hline & $\mathrm{F}$ & 0,57 & 0,38 & -32 \\
\hline & $\mathrm{C}$ & 0,54 & 1,63 & 201 \\
\hline & OEL & 0,65 & brak odczytu* & brak odczytu* \\
\hline & OEL & 13,10 & 1,38 & -89 \\
\hline
\end{tabular}

* P-1 nie wykrywało uchodzeń z przewodu otwartego do atmosfery przy niewielkich przepływach, ponieważ za mały był spadek ciśnienia na wylocie.

** Stężenie metanu podano tylko informacyjnie, ponieważ testowany egzemplarz P-1 wykrywał każdy rodzaj gazu. 
Tabela 4. Wyniki pomiarów wykonanych urządzeniem P-2

Table 4. Results of measurements made with the P-2 device

\begin{tabular}{|c|c|c|c|c|}
\hline \multirow{2}{*}{$\begin{array}{c}\text { Stężenie } \\
\text { metanu }^{*} \\
{[\%]}\end{array}$} & \multirow{2}{*}{$\begin{array}{l}\text { Nieszczelny } \\
\text { element } \\
\text { (wg rys. 2) }\end{array}$} & \multicolumn{2}{|c|}{ Strumień objętości [l/min] } & \multirow{2}{*}{$\begin{array}{l}\text { Bląd } \\
{[\%]}\end{array}$} \\
\hline & & rzeczywisty & zmierzony & \\
\hline \multirow{12}{*}{100} & V & 0,55 & 0,56 & 1 \\
\hline & V & 2,49 & 4,05 & 63 \\
\hline & $\mathrm{V}$ & 15,93 & 9,80 & -38 \\
\hline & $\mathrm{F}$ & 0,62 & 0,40 & -36 \\
\hline & $\mathrm{F}$ & 1,52 & 2,00 & 32 \\
\hline & $\mathrm{F}$ & 2,10 & 3,50 & 67 \\
\hline & $\mathrm{C}$ & 0,504 & 2,10 & 324 \\
\hline & $\mathrm{C}$ & 2,09 & 1,95 & -6 \\
\hline & OEL & 0,50 & 0,22 & -57 \\
\hline & OEL & 2,00 & 2,00 & 0 \\
\hline & OEL & 10,00 & 5,55 & -45 \\
\hline & OEL & 20,00 & 14,50 & -28 \\
\hline \multirow{5}{*}{50} & $\mathrm{~V}$ & 3,35 & 3,05 & -9 \\
\hline & $\mathrm{F}$ & 1,91 & 6,90 & 262 \\
\hline & $\mathrm{C}$ & 1,81 & 3,00 & 66 \\
\hline & OEL & 2,27 & 3,20 & 41 \\
\hline & OEL & 11,34 & 6,65 & -41 \\
\hline
\end{tabular}

${ }^{*}$ Wyniki podano jedynie dla stężeń 50\% i 100\% metanu, ponieważ urządzenie nie mierzyło uchodzeń przy niższych stężeniach.

W tabeli 5 pokazano wyniki odtwarzalności dla wszystkich badanych urządzeń. Można zauważyć, że urządzenia, które mają bezpośredni kontakt z uchodzącym gazem, charakteryzują się mniejszym rozrzutem wskazań (mniejsze odchylenie standardowe).

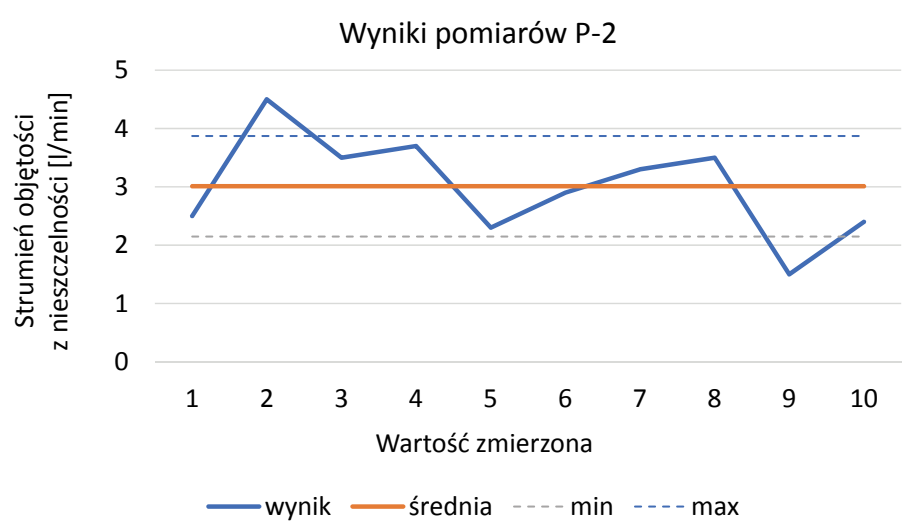

Rys. 3. Wyniki badań odtwarzalności P-2

Fig. 3. Results of reproducibility tests of P-2

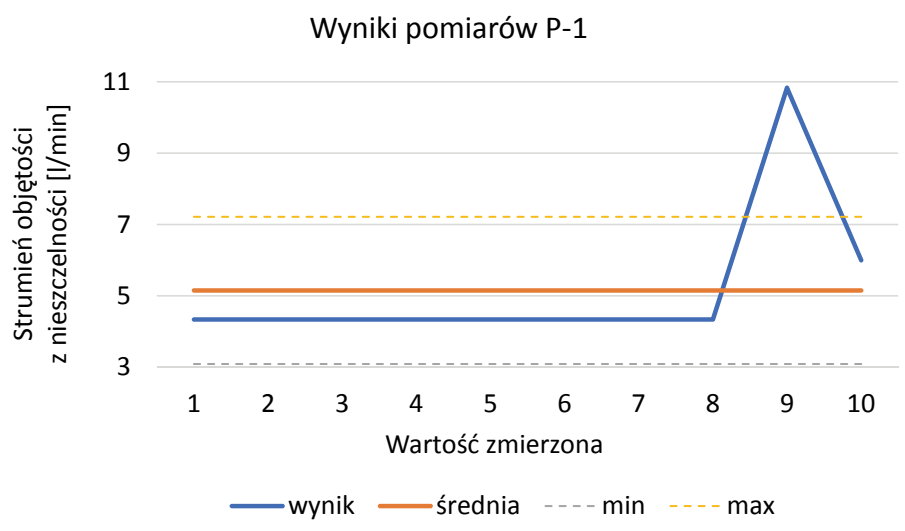

Rys. 4. Wyniki badania odtwarzalności P-1

Fig. 4. Results of reproducibility tests of P-1

1) uchodzenia o stężeniu metanu ponad 50000 ppm stwierdzono pięć takich przypadków - P-1 oraz P-2 dokonały pomiaru wielkości emisji;

2) uchodzenia o stężeniu metanu ponad $10000 \mathrm{ppm}$ do $50000 \mathrm{ppm}$ - stwierdzono trzy - nie zostały wykryte przez P-1 oraz P-2;

3) uchodzenia poniżej $10000 \mathrm{ppm}$ - stwierdzono ich dziewięć - nie zostały wykryte ani przez P-1, ani P-2.

\section{Podsumowanie}

\section{Badania polowe}

Planowano przeprowadzenie badań polowych na instalacjach magazynu gazu ziemnego w pobliżu Saragossy, jednak $\mathrm{z}$ uwagi na wprowadzone ograniczenia spowodowane pandemią (badania były przeprowadzane na początku marca $2020 \mathrm{r}$.) dokonano jedynie sprawdzenia stacji pomiarowej znajdującej się w pobliżu stanowiska laboratoryjnego.

W badaniach były użyte wszystkie wytypowane urządzenia. Wykryto łącznie 17 uchodzeń, przy czym stężenia metanu w przypadku tych uchodzeń zmierzone urządzeniami do pomiaru stężenia metanu podzielono na trzy grupy:
Istnieją dwie podstawowe możliwości określenia ilości uchodzącego gazu z nieszczelnych elementów infrastruktury za pomocą wymienionych wcześniej urządzeń:

1) pomiar bezpośredni za pomocą urządzeń, które mierzą wielkość emisji;

2) pomiar pośredni, który wymaga zastosowania korelacji umożliwiających oszacowanie wielkości emisji na podstawie wyników pomiaru stężenia metanu w miejscu występowania uchodzenia. W praktyce stosowane są korelacje podane w normie PN-EN 15446, opracowane dla przemysłu petrochemicznego. 
Zależnie od urządzenia użytkownik może wybrać albo badanie wszystkich elementów, na których może wystapić uchodzenie, za pomocą urządzeń typu sniffer, albo badanie za pomocą innego urządzenia, umożliwiającego zdalną obserwację wielu elementów infrastruktury.

Urządzenia typu sniffer najlepiej sprawdzają się przy wykrywaniu małych uchodzeń, do 50000 ppm, jednak elementy trudno dostępne wymagają zastosowania urządzeń zdalnych.

Technologie laserowe są atrakcyjne ze względu na ich szybkość działania, niewielki rozmiar, zakres pomiarowy, czułość i łatwość użytkowania, jednak ponieważ wynik jest podawany w ppm-m, przeliczenie na wartość stężenia metanu stwarza trudności.

Kamera ultradźwiękowa jest nową, obiecującą technologią umożliwiającą szybkie wykrycie uchodzenia i określenie jego wielkości w czasie rzeczywistym. Wykrywane są małe uchodzenia, od 0,03 1/min, urządzenie jest dostępne z certyfikatem ATEX. Główną wadą urządzenia jest jak na razie brak rozróżnienia rodzaju uchodzącego gazu, konieczność wystąpienia odpowiednio dużej różnicy ciśnień (50 mbar) i błąd pomiaru zależny od ustawienia i od występowania w otoczeniu zakłóceń w postaci innych źródeł ultradźwięków.

Kamera do optycznego obrazowania uchodzenia gazu nie wykrywa uchodzeń poniżej 0,4 l/min, wymaga także występowania różnicy temperatur $\left(>2^{\circ} \mathrm{C}\right)$ między chmurą gazu a tłem, a na wynik ma wpływ ustawienie kamery, która musi być zamontowana na statywie. Jest to jednak obecnie jedyna technologia, która pozwala zobaczyć uchodzenie, a dokładność określenia uchodzenia jest lepsza niż w przypadku zastosowania innych rozwiązań.

Można wysnuć generalny wniosek dotyczący urządzeń do określania wielkości uchodzenia, że błąd jest duży w każdym przypadku - około $70 \%$ dla P-2 i około $100 \%$ dla P-1. Zastosowanie urządzeń do określania wielkości stężenia metanu i korelacji podanych w normie PN-EN 15446 może jednak prowadzić do jeszcze większych błędów (Dyakowska et al., 2014).

Na podstawie przeprowadzonych badań można stwierdzić, że nie ma obecnie jednego urządzenia / jednej technologii odpowiednich do wszystkich uchodzeń, jakie mogą występować w rzeczywistych warunkach. Urządzenia do bezpośredniego określania wielkości emisji lepiej będą się sprawdzały w przypadku dużych uchodzeń, a urządzenia typu sniffer - małych.

Wyniki pracy wskazują jednoznacznie, że podczas inspekcji infrastruktury przesyłowej konieczne jest stosowanie co najmniej dwóch urządzeń - jednego do wstępnego ustalenia źródła emisji i drugiego do jej oceny ilościowej.

\section{Literatura}

Dyakowska E., Pęgielska M., 2016. Porównanie dokładności dwóch metod pomiaru emisji lotnych - wg normy EN 15446 oraz z zastosowaniem urządzenia Hi Flow Sampler - wyniki projektu GERG (The European Gas Research Group). Nafta-Gaz, 8: 660-665. DOI: 10.18668/NG.2016.08.11
Dyakowska E., Pęgielska M., Szufleński P., Fabre J.-L., Balestas D., Calzada S.A., Kashap T., Occhio L., 2014. Comparison of results obtained with different approaches to natural gas emissions measurements - GERG project no 2.73. http://members.igu.org/old/ IGU\%20Events/igrc/igrc-2014/papers/tp3-7_dyakowska.pdf/view (dostęp: 08.11.2020).

Dyakowska E., Przybył A., 2020. Emisja metanu z systemów gazowych. Materiaty konferencyjne FORGAZ 2020.

European Commission, 2020. Communication from the Commission to the European Parliament, the Council, the European Economic and Social Committee and the Committee of the Regions on an EU strategy to reduce methane emissions. Brussels, 14.10.2020, COM(2020) 663. $<$ https://ec.europa.eu/energy/sites/ener/files/eu_methane_strategy. pdf> (dostęp: 01.09.2020).

Gas Infrastructure Europe, Marcogaz, 2019. Potential ways the gas industry can contribute to the reduction of methane emissions. Report for the Madrid Forum (5-6 June 2019). <https://ec.europa.eu/info/ sites/info/files/gie-marcogaz___report_-_reduction_of_methane_emissions.pdf> (dostęp: 01.09.2020).

Global Carbon Atlas, 2019. <http://www.globalcarbonatlas.org/en/content/ welcome-carbon-atlas $>$ (dostę: 06.01.2021).

IEA, 2020. Methane Tracker 2020. Paris. $<$ https://www.iea.org/reports/ methane-tracker-2020> (dostęp: 05.09.2020).

Marcogaz, 2019. WG Methane Emissions, Assessment of methane emissions for gas transmission \& distribution system operators. $<$ https:// www.marcogaz.org/publications-1/documents/> (dostęp: 01.09.2020).

Methane Guiding Principles, 2020. Reducing Methane Emissions: Best Practice Guide Identification, Detection, Measurement and Quantification (September 2020). $<$ https://methaneguidingprinciples. org/best-practice-guides/> (dostęp: 01.09.2020).

Myhre G., Shindell D., Bréon F.-M., Collins W., Fuglestvedt J., Huang J., Koch D., Lamarque J.-F., Lee D., Mendoza B., Nakajima T., Robock A., Stephens G., Takemura T., Zhang H., 2013. Anthropogenic and Natural Radiative Forcing Supplementary Material. [W:] Stocker T.F., Qin D., Plattner G.-K., Tignor M., Allen S.K., Boschung J., Nauels A., Xia Y., Bex V., Midgley P.M. (eds.). Climate Change 2013: The Physical Science Basis. Contribution of Working Group I to the Fifth Assessment Report of the Intergovernmental Panel on Climate Change. $<$ http://www.climatechange2013.org $>$, $<$ http://www.ipcc.ch> (dostęp: 01.09.2020).

Yusuf R.O., Noor Z.Z., Abba A.H., Abu Hassan M.A., 2012. Methane emission by sectors: A comprehensive review of emission sources and mitigation methods. Renewable and Sustainable Energy Reviews, 16: 5059-5070. DOI: 10.1016/j.rser.2012.04.008.

\section{Dokumenty normatywne}

PN-EN 15446:2008 Niekontrolowana i rozproszona emisja w sektorze przemysłowym - Pomiar emisji par wydobywających się z nieszczelnych instalacji i przewodów.

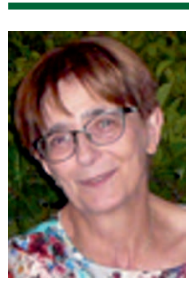

Dr inż. Eliza DYAKOWSKA

Kierownik Sekretariatu KST

Izba Gospodarcza Gazownictwa

ul. Kasprzaka 25

01-325 Warszawa

E-mail: eliza.dyakowska@igg.pl

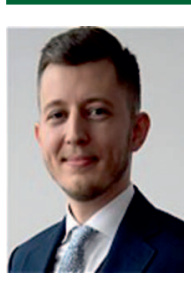

Mgr inż. Adam PRZYBYŁ

Specjalista

Dział Nowych Technologii, Pion Badań i Rozwoju

Operator Gazociągów Przesyłowych

GAZ-SYSTEM S.A.

ul. Mszczonowska 4, 02-337 Warszawa

E-mail:adam.przybyl@gaz-system.pl 